\title{
The degradation behavior of methylmercury in the soil induced by coexisiting $\mathrm{Fe}$ and $\mathrm{Cu}$
}

CAIXIANG ZHANG, MENGYING XIE, YULAN LIANG, YUNSHU ZHANG

State Key Laboratory of Biogeology and Environmental Geology, China University of Geosciences, Wuhan 430074, PR China

Methylmercury $(\mathrm{MeHg})$ is a toxic compound. It forms mainly in reducing environments, and then degrades through biogeochemical processes. In our study, the percent $\mathrm{MeHg}$ of total $\mathrm{Hg}$ in Guangzhou soil in southern China was found to be variable and exhibited a significant negative correlation with the content of $\mathrm{Fe}$ or $\mathrm{Cu}$ where annite, a Fe-bearing mineral, was identified and could activate $\mathrm{O}_{2}$ to generate $\cdot \mathrm{OH}$ and $\bullet_{2}{ }^{2-}$ and facilitate $\mathrm{MeHg}$ degradation under oxic conditions. $\mathrm{Cu}$ components in the soil further enhanced the production of $\mathrm{O}^{2-}$, and was oxidized to $\mathrm{Cu}$ (III) promoting degradation of $\mathrm{MeHg}$ directly. Meanwhile, various environmental factors, including water table fluctuation, $\mathrm{pH}$ and major ions, are discussed to clarify the behavior of $\mathrm{MeHg}$ in subsurface environments. The wetting-drying alternation can initiate $\mathrm{MeHg}$ degradation in the soil with the annite mineral. Additionally, the majority of the major ions $\left(\mathrm{K}^{+}, \mathrm{Na}^{+}, \mathrm{Mg}^{2+}, \mathrm{Fe}^{3+}\right.$, $\left.\mathrm{C}^{\mathrm{l}}, \mathrm{SO}_{4}{ }^{2-}, \mathrm{NO}_{3}{ }^{-}\right)$in the interstitial soil had little effect in the degradation of $\mathrm{MeHg}$ with the exception of $\mathrm{Cu}$, which improved the degradation depending on the $\mathrm{pH}$. At acidic $\mathrm{pH}, \mathrm{Cu}$ increased the production of hydroxyl radical while at alkaline $\mathrm{pH}$ there was oxidation to $\mathrm{Cu}(\mathrm{III})$. The products including $\mathrm{Hg}(\mathrm{II})$ and $\mathrm{Hg}(0)$ of $\mathrm{MeHg}$ degradation were also identified in this work. These findings help us understand that the distribution of $\mathrm{MeHg}$ in soil depends on not only external pollution sources, but also on biogeochemical processes in subsurface environments. 